UNITED STATES DEPARTMENT OF THE INTERIOR

Harold L. Ickes, Secretary

GEOLOGICAL SURVEY

W. C. Mendenhall, Director

\title{
Bulletin 922-B
}

\section{QUICKSILVER DEPOSITS OF THE} MOUNT DIABLO DISTRICT

\section{CONTRA COSTA COUNTY, CALIFORNIA}

BY

CLYDE P. ROSS

Strategic Minerals Invegtigations, 1940

(Pages 31-54)

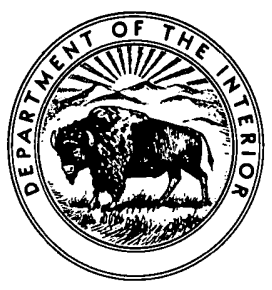

UNITED STATES

GOVERNMENT PRINTING OFFICE

WASHINGTON : 1940 



\section{CONTENTS}

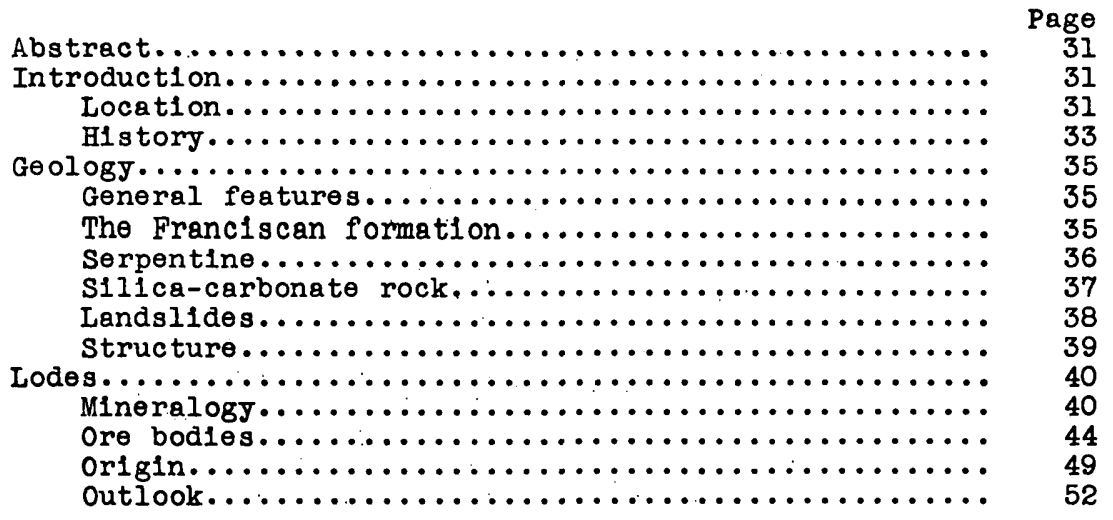

\section{ILLUSTRATIONS}

Plate 6, Geologic map of the Mount Diablo mine........ Page

34

7. Geologic map of Mount D1ablo region, Contra Costa County, Cal1f................. 35

8. Geolog1c map of M1ll Workings, Mount Diablo

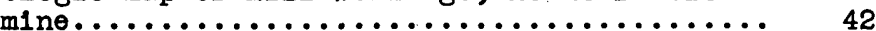

Flgure 2. Index map of part of northern Callfornla showing location of Mount Diablo district... 32

3. Structure sections through Mill Workings, Mount Diablo mine.................. 48 

QUICKSILVER DEPOSITS OF THE MOUNT DIABLO DISTRICT

CONTRA COSTA COUNTY, CALIFORNIA

By Clyde P. Ross

\begin{abstract}
The Mount Diablo district, which lies about 30 miles northeast of San Francisco, is one of the few Californian quicksilver districts that have only recently come into prominence. It has been actively productive from 1936 through 1939, and during most of that time its single operating property has been among the leaders of the industry. The lodes are in fracture zones near the footwalls of inclined, more or less tabular serpentine masses in Franclacan rocks. They are thought to have been formed by hot-spring action so recent that it is still giving rise to sulphurous gases and methane. The lodes are unlque in that metacinnabar $1 \mathrm{~s}$ an abundant primary ore mineral. The ore shoots are in zones of intense brecclation and are controlled in part by cross fractures.

When this district was visited in August 1939 work had been temporar1ly suspended because of labor difficulties and little ore was in sight in accessible workings except lowgrade materlal in open cuts; but from september 1939 at least through January 1940 the production gradually increased. The geologic setting is such as to encourage the hope that other ore shoots w1ll be found.
\end{abstract}

\title{
INTRODICTION
}

\section{Location}

The Mount Diablo quicksilver mining district is in Contra Costa County, northern California (f1g. 2), low on the easterm side of the north peak of Mount Diablo. All of the workings so far productive are in the SE⿺ sec. 29, T. I N., R. I E., Mount Diablo base and merldian, and are now held by the Bradley Mining Co. Prospects outside of this company's property were 


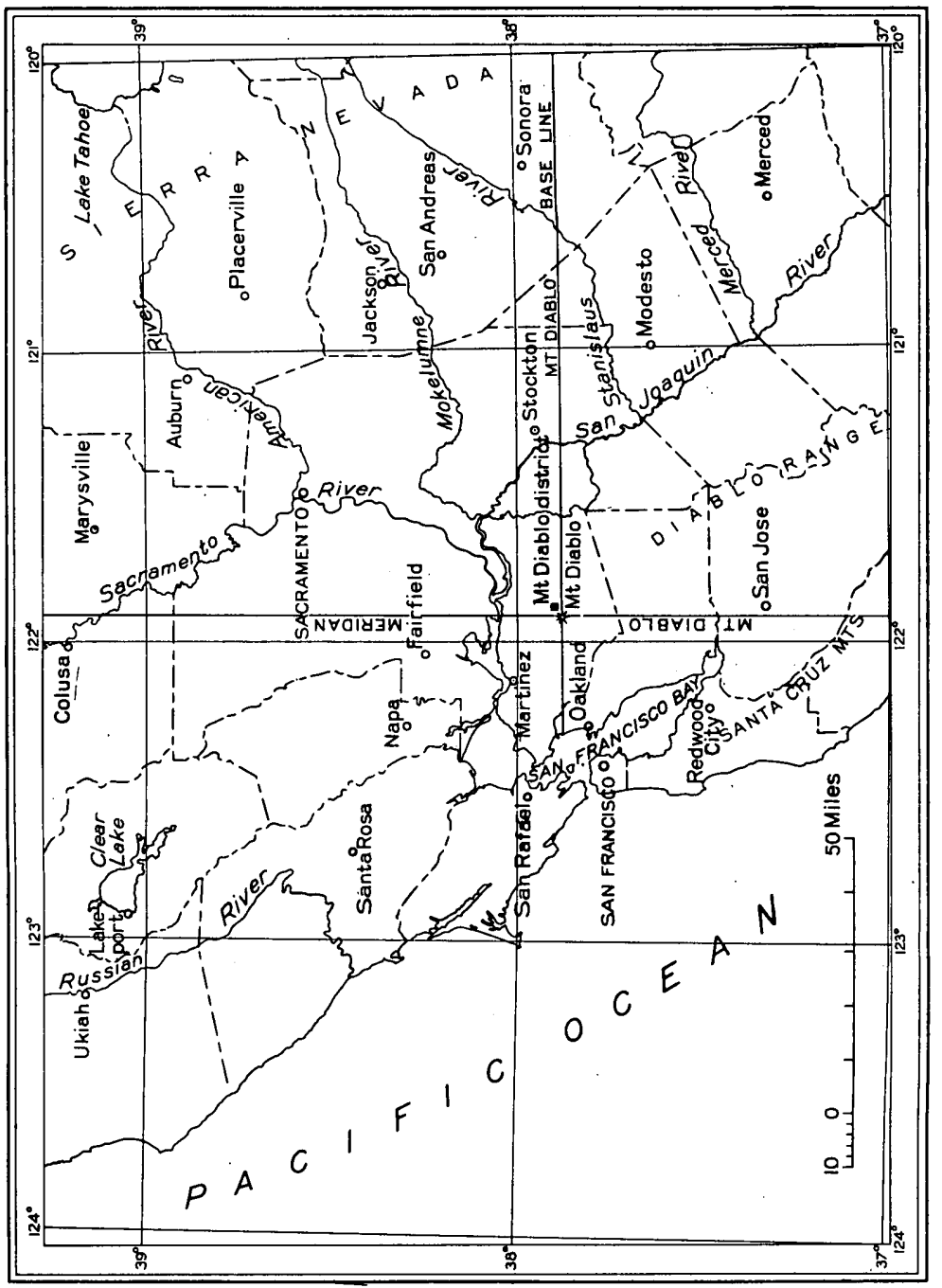

+
0
$0-1$
5
0
0
ad
0

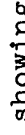

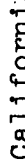

要

0

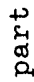

宁

0
a
$\vdots$
$x$
0
0
0
$\vdots$
$\vdots$
$\vdots$

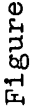


not visited during the present investigation because they have long been inactive and have never been much developed. The district is only about 45 miles by highway from San Francisco and is connected by good roads with stations on the Southerm Pacific and Western Pacific Ra1lroads and the Atchison, Topeka \& Santa Fe Rallway, so that transportation facilities are exceptlonally good.

\section{History}

Durling the boom perlod of quicksilver mining in Callfornia, the Ryne mine in the Mount Diablo district is said to have been operated successfully from 1875 to 1877 and to have produced, for a while, as much as 85 flasks of quicksilver a month. $1 /$ The workings are so scant, however, that the total production cannot have been great. Since that time there has been sporad1c activity at various prospects in the district, but the results until recently have been so meager that no reference has been made to 1 t in published reports.

C. W. Ericksen produced some quicksilver here durling the early part of 1936. The Bradley Mining Co. began operations in the district in october 1936 and was so successful that in both 1937 and 1938 the Mount Diablo mine was one of the 15 leading producers in the united States. - From the time when the rotary furnace came into operation early in 1938 unt1l work on the property was suspended in August 1939, production was at the rate of about 5 flasks dally. The suspension, caused by a labor strike, was only temporary; production was

If Irelan, W11liam, Jr.,8th Ann. Rept.of State mineralogist, for the year ending October 1, 1888 , Callfornta State M1n. Bur. Bull., p. 162, 1888.

2) Meyer, H. M., Liercury Mnerals Yearbook, 1938, p. 601; 1dem, 1939, p. 662 . 
resumed on a small scale in. September and increased steadily through January 1940. The accompanying table, published by permission of Worthen Bradley, president of the Bradiey Mining Co., gives available data on the production of the mine through 1939 .

Quicksilver production from the Mount Diablo district by the Bradley Mining Co.

\begin{tabular}{|c|c|c|c|}
\hline & $\begin{array}{c}\text { Ore produced, } \\
\text { estimated } \\
\text { (tons) }\end{array}$ & $\begin{array}{c}\text { Tenor } \\
\text { (percent) }\end{array}$ & $\begin{array}{l}\text { Quicksilver } \\
\text { produced } \\
\text { (flasks) }\end{array}$ \\
\hline $1937 \ldots \ldots \ldots$ & 2,911 & 0.40 & 304 \\
\hline $1938 \ldots \ldots \ldots$ & 8,850 & .61 & 1,422 \\
\hline $1939 \ldots \ldots \ldots$ & 12,000 & .45 & 1,423 \\
\hline Total.... & 23,761 & .48 & 3,149 \\
\hline
\end{tabular}

The Bradley Mining Co. has done a little work at the old Rhyne and Jones tunnels (pl. 6) but has concentrated most of 1ts activity at the so-called Mill Workings; some 1,500 feet farther east. These workings, which include both power-shovel cuts and underground workings (pl. 8 and flg. 3 ), are sald to be on a lode not known to the earlier operators. The mill is equipped with a 35-foot rotary furnace. When the property was visited by the writer, August 19 to 24, 1939, no work other than a little pumping was in progress; the workings below the 126-foot level were under water, and parts of the stopes above this level were inaccessible.

Cordial cooperation by Mr. P. W. Cox, the superintendent, and his staff added greatly to the effectiveness of the writer's brief examination. 


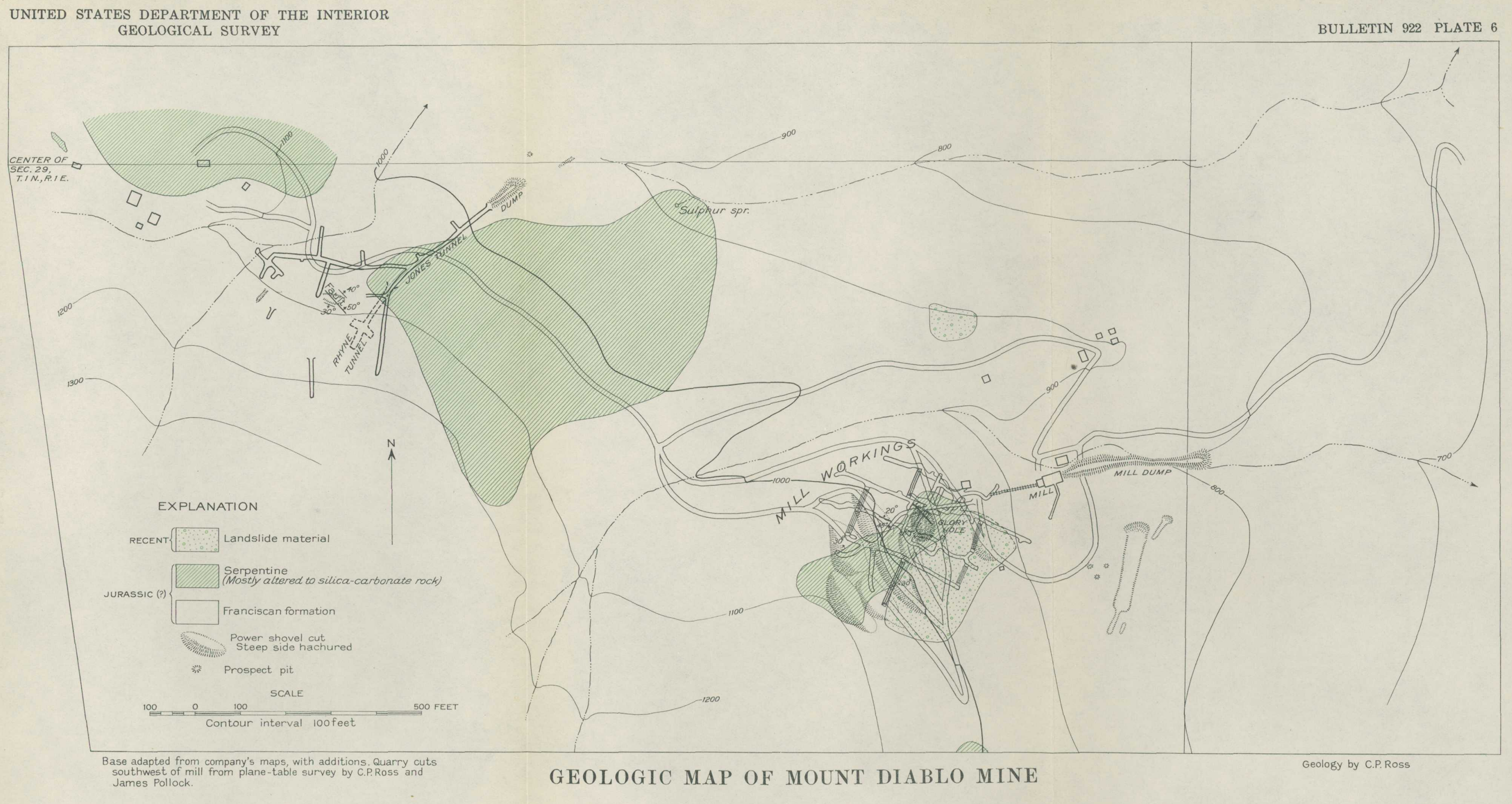




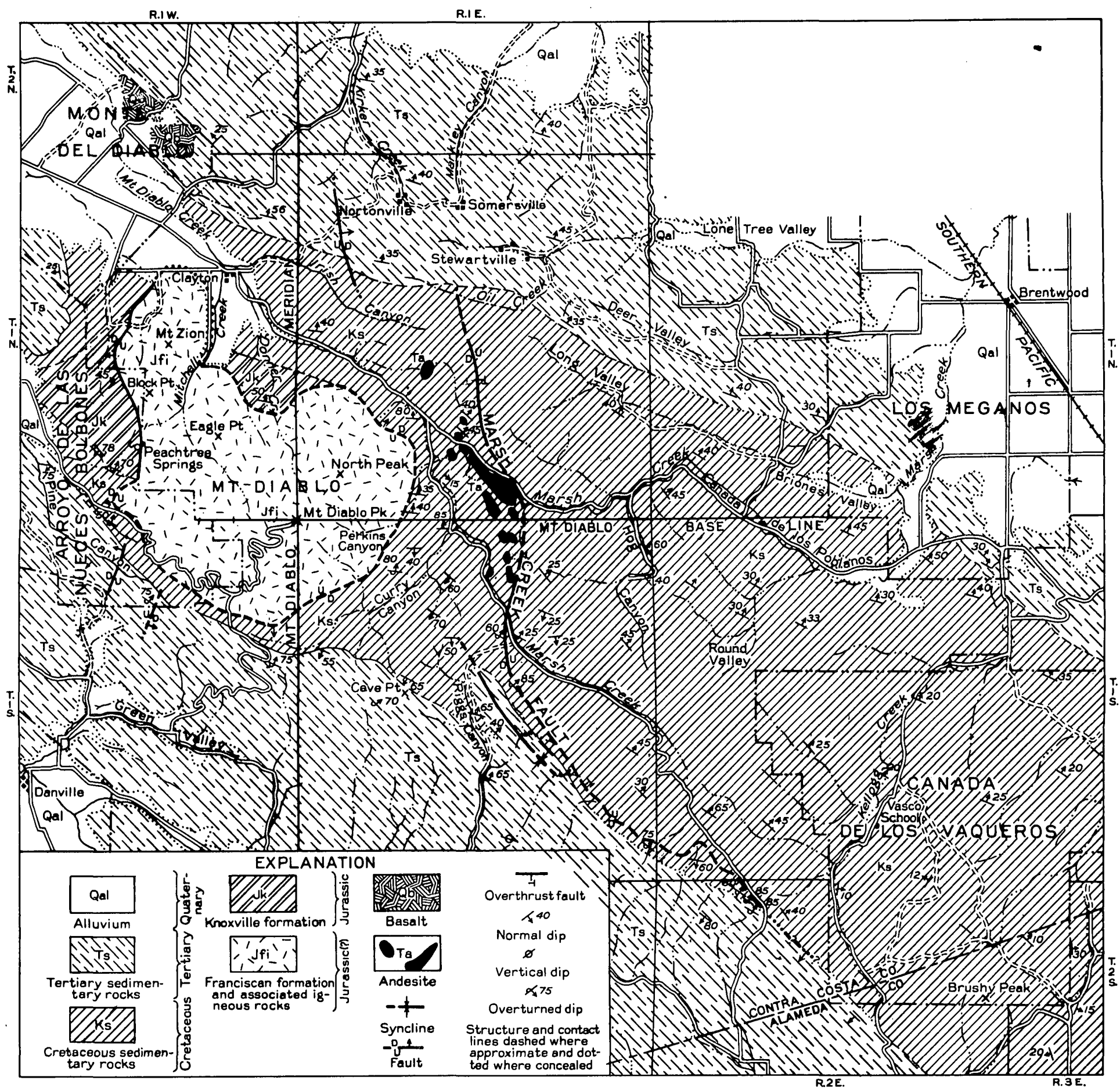

Adapted from Geol. Soc. America Bull. vol. 46, No.7, pl. 91

o 5 Miles

Geology by Joseph A.T aff and C.M.Cross 


\section{GEOLOGY}

\section{General features}

The geology of the Mount Diablo region has been studied by many geologists, but 1t has been most completely described and mapped by Taff, 3 whose map has formed the basis of plate 7. Taff has shown that Mount Diablo and the uplands around it consist of Franciscan strata, about 6,000 feet in thickness, assoclated with intrusive serpentine and other somewhat metamorphosed igneous rocks. Th1s assemblage of rocks, commonly belleved to be of Jurassic age, occuples a roughly clrcular area of about 15 square miles. It is surrounded by later sedimentary formations, whlch apparently. range in age from Jurassic to Pliocene and have a total thickness of about 35,000 feet. Small andesitic masses presumably of Tertiary age have been intruded into the lower part of the post-Franciscan strata, 4 / and higher beds are overlapped by remnants of basaltic lava flows tha: may be of Quaternary age. The quicksilver deposits occur only in the Franciscan formation, in serpentine, and in silica-carbonate rock, an alteration product of serpentine. Only these, therefore, and the landslides that locally hide them, need be further described.

\section{Franc1scan formation}

The Franciscan formation is the principal wall rock of the quicksilver deposits, and fragments of 1t, sillcifled and otherwise altered, are the principal components of most of the brecclas that contain the ore. In the area shown on plate 6 the formation consists mainly of sandstone with some shale and

3) Taff, J. A., Geology of Mount Diablo and vicinity: Geol. Soc. Amerlca Bull, , vol. $46, \mathrm{pp} .1079-1100,1935$.

IJ Turner, H. W., The geology of Mount Diablo, Callfornia: Geol. Soc. America Bull., vol. 2, p. 393, 1891. Taff, J. A., op. c1t., p. 1094.

$2372010-40-2$ 
a little chert. The sandstone is moderately coarse grained and rather dark gray where unweathered but of tawny hue where weathered. It is somewhat argillaceous and feldspathic. In certain irregular bands it is hardened and darkened by the addition of quartz and chlorite and possibly other silicates. In this metamorphosed rock, the bedding planes are especially difficult to discern.

Much of the shale forms mere partings between sandstone beds; but in places, notably underground in the Mill Workings, there are considerable bodies of dark shale, which are in part thin-bedded, although the bedding in places is indistinct. The fault linings in the mineralized areas are derived in part from this shaly material.

The small amount of chert in the Franciscan of the district 1s visible mainly as float, which occurs in a few small areas on hillsides. It is the fine-grained, thin-bedded, commonly reddish variety so plentiful in the Franciscan of many parts of California.

\section{Serpentine}

Serpentine also is the wall rock of some quicksilver deposits and hes exerted some control over the distribution of mineralized shear zones. Three relatively large masses of serpentine are falrly well exposed in the area mapped (pl. 6). They are roughly tabular and extend along the bedding, and it is possible that the two more westerly ones originally formed a single body. Thin sheets of serpentine occurring near the western border of the area were not mapped. Scattered outcrops near the southeastern corner may represent a larger body than 1s shown on the map, the exposures being here so widely soattered that their interpretation is uncertain. 
In general, the serpentine is somewhat more resistant to erosion than the surrounding Franciscan rocks, and the three larger masses crop out in relatively prominent topographic features. The rock is mainly of what palache $5 /$ calls the slickensided facies; its prevaling color is plstachio green, and 1t breaks readily on curved, smooth, glistening surfaces. The hand specimens taken show little trace of the original Igneous rock from which the serpentine was derived.

That the parent magma of the serpentine was intruded into the Franciscan formation 1 s most clearly shown by the fact that offshoots from the main bodies of serpentine cut irregularly across the bedding of the adjacent sedimentary rocks. Narrow tongues of serpentine also extend along the bedding planes of the enclosing sandstone.

\section{Silica-carbonate rock}

Much of the serpentine within the mapped area has been altered into what is commonly called silica-carbonate rock or calc-s1lica rock. This kind of altered serpentine is called "quicksilver rock" by some because it is so commonly present in the vicinity of quicksilver lodes; but it is by no means restricted to such localities, and it may be mainly an end product of the series of hydrothermal changes of which the serpentine itself represents only one stage. It, therefore, should not be regarded too implicitly as a guide to ore. Here, as in other parts of the Coast Ranges, $6 /$ the silica-carbonate rock consists largely of chalcedony and quartz, w1th some dolomite and other carbonates and small amounts of pyrite, chromlte, opal, and nickel silicate. The less thoroughly

5/ Palache, Charles, The Therzoll te serpentine and associated rocks of the Potrero,San Francisco: Callfornia Univ., Dept. Geology, Bull. 1, pp. 163-165, 1894.

6] Xnopf, Adolph, An alteration of Coast Range serpentines California Univ., Dept. Geology, Bull. 4, No. 18, pp. 425-430, 1906. 
replaced material retains some serpentine. Much of $1 t$, especlally in surface exposures, is stained with iron and manganese oxides. Much of it is irregularly and indefinitely banded in white and black. The bands probably reflect the roughly schistose structure of the serpentine. In places the sil1ca-carbonate rock has been shattered and recemented by additional chalcedony and carbonates. In a few other places the carbonates have been leached out, leaving a honeycombed mass of chalcedony and opal.

Some of the sandstone close to the serpentine bodies contains small tongue-shaped aggregates formed by the impregnation of the sandstone with alteration products similar to those that constitute the silica-carbonate rock. These tongues are lighter-colored than the surrounding sandstone but merge into 1t.

\section{Landslides}

Landslides are exceptionally common in the general vicin1ty of Mount Diablo. Two that are sufficiently well defined to be mapped approximately are shown on plate 6. The more southerly of these extends deep enough to be cut by workings on the tunnel level. Here the material consists of angular to subangular fragments, mainly of sandstone, embedded in yellow and red clay. Similar material, which may be an extension of the same landslide, is exposed at the mouth of the large cut south of the mill dump. The two landslides mapped have falrly definite topographlc expression and are readily recognized for what they are; but hillside creop is so prevalent that much of the surface is underlain by landsildes whose limits are not known. Only the larger outcrops in this region, therefore, can safely be regarded as undisturbed, a fact that hampers prospecting as well as geologic study. 


\section{Structure}

Several opinions have been offered to explain the structure of the region $7 /$ but the one now most generalis accepted is that proposed by Taff. He belleves that the complex of Franciscan and associated rocks was shoved or protruded through the post-Franciscan beds in Quaternary time. He attributes the numerous landslides in the region to weaknesses developed in the rocks by this disturbance.

The local structural features that most closely control the distribution and size of ore shoots are shear zones near the contact between serpentine and Franciscan strata. Minor fractures roughly normal to the shear zones may influence the distribution of ore minerals. These and other local structural features are shown on plates 6 and 8 .

The most conspicuous structural feature is a general northeasterly dip of the Franciscan strata, though local southwesterly dips occur. The main serpentine bodies also dip northeastward but do not conform exactly in dip to the strata and in general are bluntly terminated.

A few faults of northwesterly trend are shown on plate 6 . Most of these are marked by brecclas and some by abrupt changes of dip. Some of the sandstone at a distance from the faults mapped 1s locally brecclated, and minor faults of northeasteriy trend are visible in the M1ll Workings (pl. 8) but were not detected in surface exposures. Only the faults that could be mapped with assurance are shown on plate 6. If exposures had been better and distinctive beds had been traceable, the faults

7f Clark, B. I.. Thrust faulting in the Mount Diablo region of midile Calffornia (abstract): Geol. Soc. America Bull., vol. 36, p. 152, 1936. Louderback, G. D., Chief features of the stratigraphy and structure of Mount Diablo, California (abstract): Geol. Soc. America Bull.,vol. 19, pp. 537, 539, 1909. Taff, J. A., op. cit., pp. 1096-1100. 
would probably have been found to be longer and more numerous than shown. The amount of throw on the faults is not evident, but 1t seems without exception to have been small, for the faults along the serpentine contacts have scarcely disturbed the irregular projections thereon. The boundaries of the serpentine are sinuous and essentially intrusive, al though there has been much shearing along them.

\section{LODES}

Quicksilver has been reported from several deposits near Mount Diablo but only those on the property of the Bradley Mining Co. have recelived much development and are the only ones here described. These lodes are unique in that metacinnabar is an abundant primary ore mineral. Other constituents of the ore include cinnabar, marcasite, pyrite, quartz, and fragments of wall rock. The deposits are in fracture zones near the footwalls of serpentine masses in Franciscan rocks and are thought to have been formed so recently that sulphurous gases and methane st1ll rise.

\section{Mineralogy}

The lodes examined contain metacinnabar, cinnabar, marcasite, pyrite, and quartz, mingled with the constituents of the country rock, whlch may be sandstone, shale, or silica-carbonate rock. A little bituminous material is present, especially in what is called the "black alta" by quicksilver miners. Hydrogen rulphide, sulphur dloxide, and methane are so plentiful underground that faint odors of them are prevalent, and open lights are prohibited because of the danger of explosion. Iron sulphates of different kinds are widely though rather sparsely distributed underground. A little secondary calcite occurs on seams. 
The outstanding mineralogic feature, at least. in the M1ll Workings, is the abundance of metacinnabar. Schuette has pointed out that though metacinnabar may be sparingly present in many quicksilver deposits, it is rarely so plentiful as to be of economic significance or even to be positively ident1fled. In the Mill Workings it is one of the principal ore minerals. At the time of visit, the best accessible exposure of metacinnabar ore was in a stope pillar at the side of the main drift on the 60-foot level about 15 feet southeast of the main winze. The following description applies particularly to this exposure. The altered sandstone has been so thoroughly shattered that many of the fragments are less than an inch in diameter. The most of the fragments are sharply angular and 1rregularly jumbled, but in the more thoroughly crushed and mineralized portions, many of the fragments are as well rounded as pebbles in a stream bed. The matrix between the fragments is abundant and is composed mainly of sulphides. Most of the quicksilver sulphides appear to consist of intimate mixtures of cinnabar and metacinnabar, which form indistinctly banded, botryoldal masses. The cinnabar is the younger of the two sulphides. The dark metacinnabar masks the characteristically bright-red cinnabar, which, therefore, seems at first glance to be less abundant than it really is. In some aggregates so dark that at first glance cinnabar seems absent, the red sulphide is even more abundant than the black. The two are seen in polished section to form an aggregate of twinned anisotropic grains that in places seem to intergrade into each other. The grains of faintly bluish metacinnabar,

8/ Schuette, C. N., Occurrence of quicksilver ore bodies: Am. Inst. Min. Het. Eng. Trans. 1931, pp. 412-413. 
in part rounded by corrosion, seem to float in the creamcolored cinnabar. In most of the material the red color of the cinnabar is not visible in the polished section except along scratches and cracks, and even here it can scarcely be seen unless means are used to produce internal reflections. Some of the more coarsely granular aggregates of cinnabar, however, show brilliant red by internal reflection without being scratched. Most of these distinctly red aggregates seem to cut the more complexly twinned aggregates. In places red films line the contacts between successive botryoldal bands of the complex aggregates.

Some of the ore left in the stopes contains distinctly crystalline cinnabar without visible metacinnabar. In some of the stopes close to the tunnel level cinnabar appears to have been the principal valuable component of the ore. The earthy bright-red variety commonly called "paint" is even more widely distributed, both in surface cuts and underground, but commonly in amounts too small to affect the tenor of the ore greatly. As only a little ore was seen in place and the black metacinnabar, especially if sooty, is hard to see underground, the writer was unable to estimate the relative abundance and distribution of the different varieties of quicksilver sulphide. According to the superintendent, P. W. Cox, metacinnabar not only is one of the most abundant sulphides In the Mill Workings but also apparently increases proportionately with depth.

Both marcasite and pyrite are commonly present and locally abundant. Much of the pyrite constitutes residual grains, in part intricately embayed, that are embedded in the quicksilver minerals, but well-formed untarnished pyrite cubes stud the walls of some vugs. Marcasite is the more abundant of the two iron sulphides. Most of it is enclosed in and partly embayed 
UNITED STATES DEPARTMENT OF THE INTERIOR GEOLOGICAL SURVEY

BULLETIN 922 PLATE 8

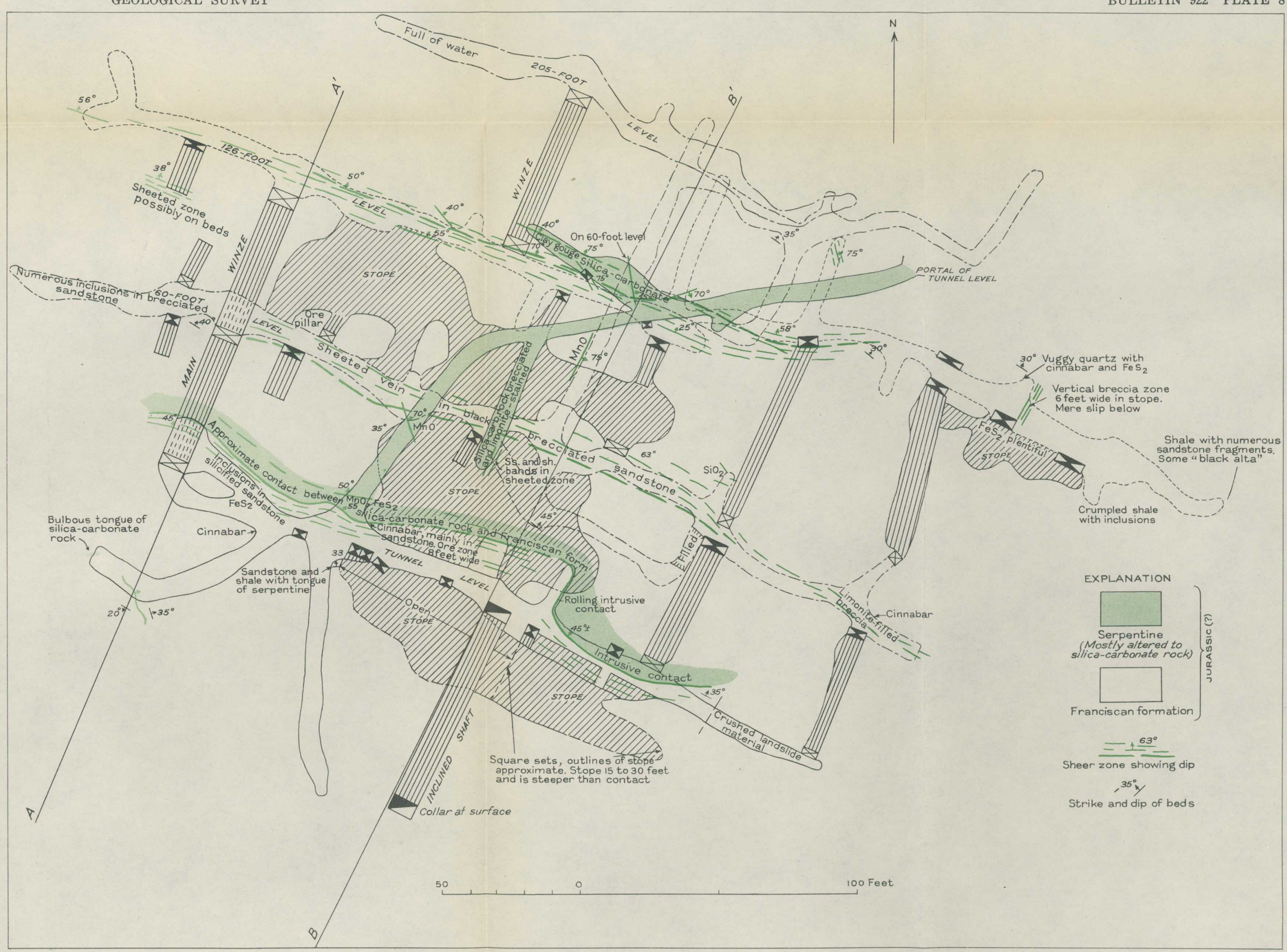

GEOLOGIC MAP OF MILL WORKINGS, MOUNT DIABLO MINE 
by the quicksilver minerals and must, therefore, have crystallized earlier than these; but much of 1t forms uncorroded crystals. Much of the marcasite in the larger openings between sandstone fragments is in crustifled bands, and where the openings are not completely filled they are commonly lined by the crystal-studded surfaces of such bands. Marcasite also forms filaments that ramify through the sandstone. Most such materlal fills tiny cracks, but here and there marcasite crystals enclosed in unbroken sandstone were presumably formed by replacement. Stringers, fllaments, and scattered grains of the fron sulphides, mainly marcasite, are widely distributed in small quantities in the sedimentary rocks throughout the mine and are relatively abundant in the crushed, carbonaceous black clay, which is described below.

Quartz, generally in subordinate amounts, $1 \mathrm{~s}$ mingled with the sulphides in the open spaces of the breccia and also has impregnated the sandstone extensively. In places small wellrounded fragments in the breccia are composed of vein quartz. These are coated with sulphides fust as the sandstone fragments are. Distinct quartz veinlets are rare. The white and pale-colored veinlets and fragments of veinlets that are localIy consplcuous consist of mineral aggregates similar to those of the s1l1ca-carbonate rock (see pp. 37-38) and l1ke that rock presumably are much older than the quicksilver minerals.

Some of the fault fractures are lined with the soft dark material, black alta. Crushed portions of some of the more arg1llaceous Franciscan beds that are not on distinct faults consist of similar material. According to C.S. Ross, $\frac{9}{\text { this }}$

9/ Ross, C. S., personal communt cation. 
is composed largely of clay of the beldellite-montmorilionite group. He found that its mean index of refraction $1 \mathrm{~s} 1.50$ and its birefringence approximately 0.03 . It is thus low in iron. The nearly black color results from an apparently rather large content of bituminous matter.

Sulphates of several kinds are wldespread through the underground workings, especially in drifts and crosscuts that invade the hangling wall far enough to have been left relatively undisturbed for comparatively long periods. Cavities in the ore of the pillar already referred to contain siderotil $\left(\mathrm{FeSO} \mathrm{S}_{4} \cdot 5 \mathrm{H}_{2} \mathrm{O}\right)$, which may be derived by dehydration from melanterite $\left(\mathrm{FeSO}_{4} \cdot 7 \mathrm{H}_{2} \mathrm{O}\right)$, one of the more widespread and more abundant sulphates. Epsomite $\left(\mathrm{MgSO}_{4} \cdot 7 \mathrm{H}_{2} \mathrm{O}\right)$, or a somewhat dehydrated form of this salt, is locally present in the ore zone but is not as abundant as in many quicksilver mines that have stood open for longer perlods. At the end of the crosscut that extends farthest to the, north on the 60-foot level the sulphate aggregate consists, according to Charles Milton, of the Geological Survey, mainly of copiapite $\left(\mathrm{Fe}_{4}(\mathrm{OH})_{2}\left(\mathrm{SO}_{4}\right)_{5}\right.$. $\left.17 \mathrm{H}_{2} \mathrm{O}\right)$ with a little roemerite $\left(\mathrm{FeSO}_{4} \cdot \mathrm{Fe}_{2}\left(\mathrm{SO}_{4}\right)_{3} \cdot 14 \mathrm{H}_{2} \mathrm{O}\right)$. The mixture contains some arsenic, antimony, nickel, and magnesium with little, if any calcium. Samples collected close to the ore zone on each of the three accessible levels were found by Milton to consist of melanterite and halotrichite $\left(\mathrm{FeSO}_{4}\right.$. $\left.\mathrm{Al}_{2}\left(\mathrm{SO}_{4}\right)_{3} \cdot 22 \mathrm{H}_{2} \mathrm{O}\right)$. The melanterite tested contains about 2.5 percent of nickel.

\section{Ore bodies}

Until recently mine exploration in this district has been meager and with minor exceptions has been confined to the small area shown on plate 6. Presumably the Rhyne tunnel and nearby open cuts shown on that map correspond broadly to the 
mine reported to have been active in the late seventies, even though the name of that mine was spelled Ryne. $10 /$ The nearby Jones tunnel appears to have been opened much more recently, and what is here termed the M1ll Workings does not appear to have been started until 1936. All these workings follow fracture zones in Franciscan strata and altered serpentine, all of which appear to be close to the footwall sldes of tilted serpentine bodies. Those listed above are the only workings visited during the present investigation, but Turner ll/ noted that he saw cinnabar, with chalcopyrite and calcite, on the contact between post-Franciscan shale and a small mass of mica andesite in a butte near a branch of Mason Creek, roughly a mile southeast of the area here described. He also spoke of an iron-stained quartz vein with cinnabar a mile south of the "main peak" (presumably Mount Diablo).

The Jones and Rhyne tunnels and nelghboring cuts explore breccla zones of northwesterly trend about which little information was obtained. The Jones tunnel, the lower of the two, with 1 ts branches aggregates about 1,200 feet of workings but is caved 70 feet from the portal. It is probably all in the Franciscan formation. The remains of a bank of retorts are visible a short distance down the slope from the portal of the Jones tunnel, and quicksilver ore is reported to have been mined from this tunnel. The Rhyne tunnel, a crosscut 165 feet long, has a transverse drift about 50 feet from its face. The portal is in silica-carbonate rock, but the rest is in Franciscan strata. The sandstone in the drift is altered and

10/ I relan, William, Jr., op. c1t., p. 162.

1I/ Turner, H. T.. The geology of Mount Diablo, Cal1f.8 Geol. Soc. America Bull., vol. 2, pp. 391-392, 1891. 
intensely brecclated along a zone that trends $\mathrm{N} .55^{\circ} \mathrm{W}$. and dips $40^{\circ} \mathrm{NE}$. No ore was noted here, but this crushed zone is presumably related to the lode from which the early production of the Rhyne mine came.

At the Mill Workings the surface excavations include four benches and a glory hole, as well as scattered prospect cuts. Some of these cuts, as plate 6 shows, are of considerable size. Most of the surface excavations have been made by power shovels. The underground workings (pl. 8) are reached through a tunnel whose portal is between the mill and the benches just mentioned. There are drifts and exploratory crosscuts on the tunnel level and on two other levels 60 feet, 126 feet, and 205 feet, respectively, below 1t. The levels are connected by an abandoned shaft from one of the benches to the tunnel level, a winze from this level to the 126-foot level, and another winze from here to the 205-foot level. Stopes extend down as far as the 126-foot level. Together the surface cuts and underground workings extend through a vertical range of about 400 feet. At the time of visit low-grade ore was reported to be present in the surface cuts, particularly the lower benches. The ore so far mined in these cuts was of lower average tenor than that obtained underground, and considerable waste rock had to be moved by the shovels. On and above the tunnel level the stopes are southeast of the entrance tunnel, whereas on the next two levels below they are progressively farther to the northwest. Stopes range between 100 and 150 feet in length, and in width they are rarely more than 20 feet. There is a small stope on a separate ore shoot in the southeasterm part of the 126-foot level. The average tenor of the ore (see p. 34) was 0.48 percent, or nearly 10 pounds of 
quicksilver to the ton. The quicksilver sulphides were 1rregularly distributed within the breccia zones so that in places the tenor may easily have been more than twice the average. Outside these zones the quicksilver content, at least in the sandstone, is probably almost negligible.

The serpentine mass explored in the Mill Workings is an 1rregular blunt-edged body, now largely altered to silicacarbonate rock. It extends fully 400 feet in the direction of dip. It is somewhat more than 150 feet wide near the top of the shovel benches and about 250 feet wide on the tunnel level but does not extend far enough to be cut on the lower levels. It is from 50 to more than 100 feet thick. The shape of the serpentine mass and 1ts relations to the mineralized shear zones are necessarily somewhat generalized in the two vertical sections in figure 3. The mass strikes about $N \cdot 35^{\circ} \mathrm{W}$. and dips about $50^{\circ} \mathrm{NE}$. The Franciscan strata cut by 1 t strike N. $50^{\circ}-60^{\circ} \mathrm{W}$. and $\operatorname{dip} 30^{\circ}-45^{\circ} \mathrm{NE}$., with local varlations outside these IImits.

The main shear zone lies along the lower contact of the intrusive mass but extends as far below it as the mine workings have yet reached. There are roughly parallel secondary fracture or shear zones within the serpentine, and one of these has been explored in the glory hole. In addition, both the serpentine and the Franciscan beds are locally broken by cross fractures roughly normal to those mentioned above. According to superintendent Cox, much of the better ore is associated with minor cross fractures within the main ore zone, and, although no clear examples of this relation were seen during the present examination, such a relation is to be expected from observations on other quicksilver lodes in the Coast Ranges. 

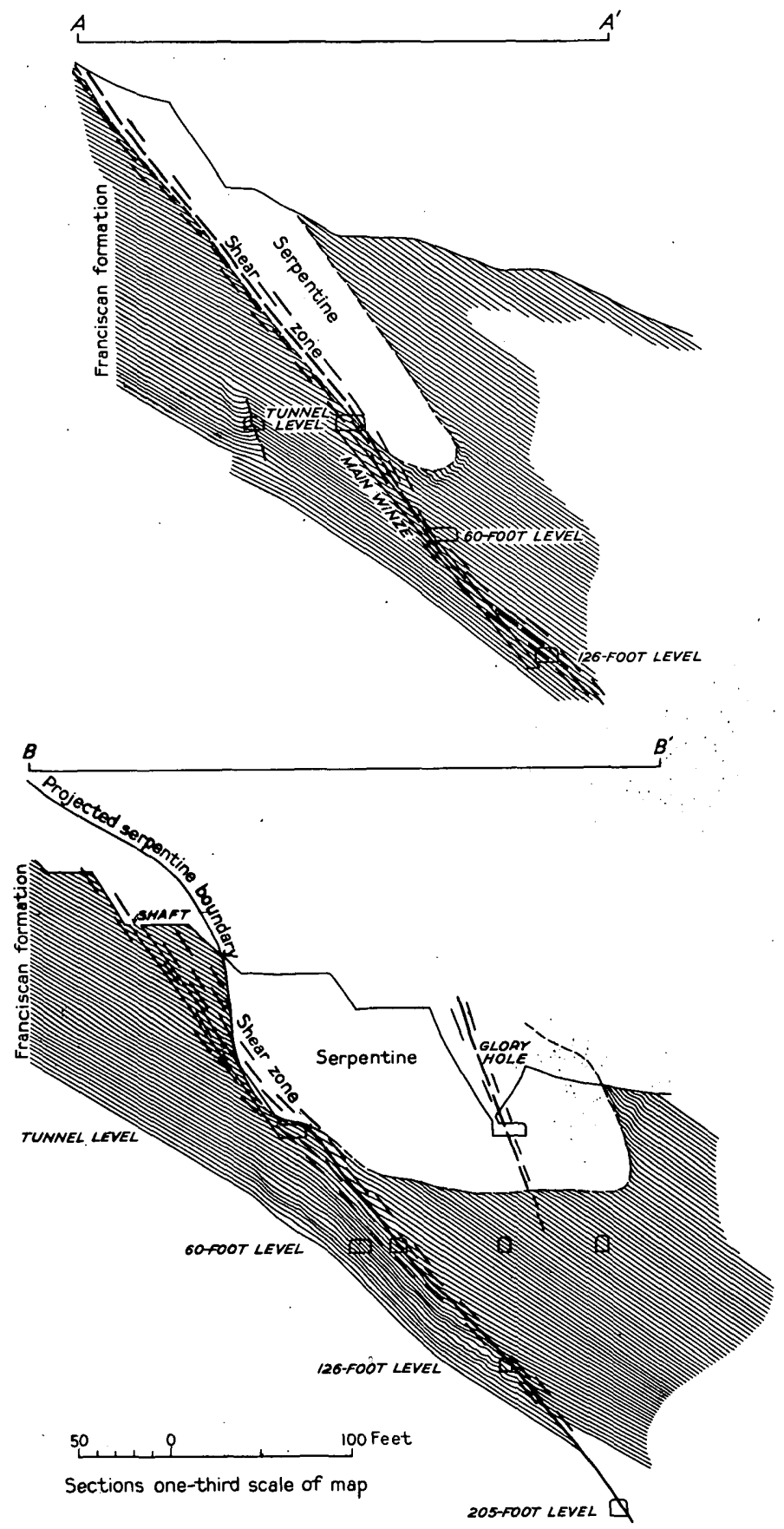

Figure 3.--Structure sections through Mill Workings, Mount Diablo mine. 
All the larger fracture zones exposed underground are made up of numerous subparallel shear planes. In most places in the main zone, which passes along the base of the serpentine, a single shear plane seems more prominent and more continuous than the rest. This is indicated on plate 8 and figure 3 by the relatively heavy lines. The sandstone within the shear zones is extensively shattered. The breccias are composed mainly of sandstone but include silica-carbonate rock, sandstone altered in simflar fashion, and veln quartz. The vein quartz, which is confined to ore shoots, records movement that occurred after deposition of lode minerals began. In spite of the evidence of marked disturbance, in part comparat1vely recent, the amount of displacement in the shear zones is small. This is inferred mainly from the fact that the shear zone follows the distinctly irregular intrusive contact closely. In places there are profections of the contact that would have been sliced off if much displacement had taken place. The sharp bend in the serpentine contact explored by a short crosscut on the tunnel level just east of the shaft is an example of the sort of 1rregularity that should have been obscured by

a fault of large displacement.

\section{Origin}

The lodes of the Mount Diablo district appear to have been deposited from hot waters that derived their metalilc constituents from distant magmatic sources. Deposition took place In successive stages relatively close to the surface and in geologically recent time. It was confined to zones of crushIng and shearing that served as channels for the rising solutions and provided adequate open spaces for deposition of the sulphides. The geologic features of the district have much In common with those of many of the other quicksilver districts in the Coast Ranges of California. The most distinctive char- 
acteristics of the Mount Diablo district are the relative abundance of metacinnabar, sulphates, and gases. In the Mount Diablo area the rock is perhaps more extensively crushed and the amount of open space that has survi"od mineralization is even greater than in other districts. These distinctive features are all in accord with the concept that the lodes of the Mount Diablo district formed close to the surface and more recently than many of the others in the Coast Ranges. This statement does not necessarily imply that they belong to a different period of ore deposition.

Deposits thus formed are shallow as compared with many kinds of metalliferous lodes, but the vertical range in which they may occur is far greater than that jet explored in the Mount D1ablo district. Ore shoots may have originally formed at intervals through a vertical distance of hundreds or more probably thousands of feet, and the deposits in this district are so recent geologically that the depth of erosion since mineralization probably has not been great. A more potent factor in respect to practical limits of depth is the fact that ore shoots are so small and so irregularly distributed that their positions are difficult to predict. The relatively light lood under whlch the lodes were formed is in part responsible for these conditions.

The warm springs near the Mount Diablo mine and those near many other quicksilver mines may represent dying stages of the hot-spring activity that produced the mineral deposits. The gases that still circulate through the lodes are likewise related to hot-spring processes. It does not follow, however, that either modern hot-spring water nearby or gases within the mines have the same composition as the solutions from which 
the ore minerals were deposited. The presence of both pyrite and marcasite and of both cinnabar and metacinnabar shows clearly that changes in the character of the solutions occurred while mineralization was in progress. Other such changes have surely occurred since it ceased.

It seems clear that nearly all of the sulphide minerals are products of the original mineralization, deposited from ascending water. The metacinnabar is earlier than much or all of the cinnabar. The cinnabar, which is the more stable form of quicksilver sulphide, may have formed in part by inversion from the previously crystallized metacinnabar. At all events, 1t seems clear that the metacinnabar in the crystalline aggregates of botryoldal form is not a supergene product, as this mineral is commonly supposed to be. Chemical data, recently summarized by Dreyer, $12 /$ show that metacinnabar may be formed from rising solutions in an acid environment and may invert into cinnabar.

In the Mount Diablo district, as in many others, the effects produced on quicks1lver ores by descending waters appear to be trivial economically. It seems possirle, however, that at least part of the "paint" cinnabar resulted from solution and redeposition by such waters. Even though widely distributed, the mineral in this form everywhere occurs in relatively subordinate amounts. It is all within the mineralized bodies and close to original quicks1lver sulphides. Thus it is probable that such redistribution as it records has not appreciably affected the tenor of the ore. In places the ironsulphide minerals are still fresh and bright, but in parts of the stopes they are blackened and partly decomposed, presumably as a result of oxidation since the workings were opened.

12/ Dreyer, R. M., The geochemistry of quicksilver mineralization: Econ. Geology, vol. 35, No. 1, pp. 17-48, 1940. 
Most of the sulphates widely distributed in the workings also formed after the mine was opened, as is shown by the fact that they coat artificial surfaces. Features of this sort are somewhat unusually prevalent for a mine so recently opened. It seems probable that the gases that rise through the workings have speeded-up and modifled the processes by which sulphates are produced. The effects now visible are thus the result of weathering agencles and hot-spring emanations working together.

\section{Outlook}

Development in the Mount Diablo district has fortunately been carried out by an adequately financed company with trained personnel. The nearmess of the district to San Francisco is also an outstanding advantage. So few quicksilver districts have these advantages that even those with favorable geologic environments are handicapped in their development. Consequently the rapid development of the Mount Diablo district stands out. W1th a few consplcuous exceptions, most quicksilver mining districts are continuously productive for only a few years. The good production record of the Mount Diablo district from 1937 through 1939, therefore, In 1tself holds no promise that a comparable record can be long maintained. The material of comparatively low grade around the shovel benches above the $\mathrm{mlll}$ and in other parts of the property may serve to prolong production, especially if high prices continue, but the ore bodies from which recent production has come will soon be exhausted. It is entirely possible that other similar shoots exist. Whether they will soon be found depends largely on whether market conditions remain such as to encourage active expensive exploration. In this as in 
many other quicksilver districts, clues to the location of undiscovered ore shoots are not plain enough to encourage the hope that search for them will be quickly successful.

The meager development already accomplished has disclosed several ore shoots. Only a few quicksilver mines in california have jielded any large proportion of their profitable production from shoots at depths materially greater than those already attained in the M1ll Workings; hence, it may be well to test thoroughly the ground above the present bottom level before any extensive sinking program is undertaken. The crosscuts driven into the hanging wall in the Mill Workings have not ylelded encouraging results. The possibilities here have not been exhausted, but 1t might be wise as a next step to explore the footwall, where comparatively little exploring has been done. If sultable open crushed zones exist here, they may well contain ore shoots elther at the intersections of conjugate fractures or at places where overhanging bands of black alta or other impermeable material may have served to check the upward passage of solutions. The possibility that ore shoots may 110 along conjugate fracture zones should not be overlooked. Any such shoots would trend so nearly normal to the strike of the principal ore zone in the present M1ll Workings as to complicate search for them.

Surface prospecting should be extended into surrounding areas. If, as reported, the mineralized zone of the Mill Workings was unknown unt1l recently, other deposits may have been overlooked in this country of poor outcrops and numerous landslides. Particular attention should be paid to the foot- 
wall sides of tilted serpentine lobes and sills, especially where silica-carbonate rock is plentiful. Breccia zones in other locations should not be overlooked. By using moderm bulldozers it is relatively easy to expose bedrock in spots shown to be favorable by examination of float. 